\title{
Analysis on Teaching Methods of English for Business
}

\author{
WANG Youyue \\ Sichuan College of Architectural Technology, Deyang, Sichuan, 618000, China
}

\begin{abstract}
English is a language used widely across the globe. As an important spot for cultivating social talents, universities and colleges should focus on practicality of English teaching. The teaching goal is to fully display the role of English in communication, so that the personnel cultivated can serve social construction better. With economic globalization and further development of reform and opening-up in China, business has been an important field for English application. Thereupon, English teaching needs to keep pace with times and combine itself with business situations. Meanwhile, more attention should be paid to the practice and innovation of the teaching methods. Therefore, students are expected to learn independently to master English application skills.
\end{abstract}

KEYWORDS: Business application; English teaching; discussion method; case method; situational method.

\section{INTRODUCTION}

Business English is an important specialized course in higher education, mainly for international trade, marketing, accounting and other majors. This English-based course introduces business knowledge so as to foster students' business communication competence in English. Business English highly values the application capabilities of English. Through teaching process, students are expected to improve their business communication competence in English environment. Due to the great practicality of this course, it's very demanding in students' application capabilities of English. With economic globalization, business English is gaining wider application, giving full play to the role of English in social development and economic construction. This course is of great significance to students' personal development, comprehensive capacity building, employment and entrepreneurship. The choice and application of teaching methods are important for English learning [1]. The key to teaching success lies in the reform from traditional score-oriented pedagogy which ignores students' speaking and listening skills. Thus, a scientific, efficient and applicable teaching method is very necessary.

\section{ANALYSIS ON TEACHING OF ENGLISH FOR BUSINESS}

\subsection{Present situation of business English teaching}

Business English teaching should be conducted with business knowledge as the core and the language of English as the basis. Currently, the disconnection between theory and practice is the biggest problem in business English teaching. Firstly, business English teaching emphasizes the application of English in business activities. However, in current English teaching, traditional methods are still adopted with focus on vocabulary, sentence patterns and text translation. In this case, the theme of business application has not been highlighted, causing a disconnection between the teaching contents and the practicality of English. Secondly, business English teaching is overly rigid. It overemphasizes teaching form rather than the content [2]. For example, the teaching of English writing is mostly confined to business letters or telegraph texts. With the knowledge hard to expand, students find it difficult to put the knowledge into practice. Thirdly, in English teaching process, students are not able to achieve their dominant status while the teacher-centered situation is even harder to change. Students fail to participate in English teaching due to inadequate awareness and weak competency. However, teachers in a stronger position take on all things without enough inspiration and guidance to students. They simply indoctrinate students with knowledge. 
Students then are compelled to memorize it so as to pass the exam. Little consideration is taken for the cultivation and improvement of students' comprehension and application ability. Fourthly, English teaching has deviated from the actual business environment [3]. As the teachers are limited in their business expertise and practice, they have difficulty in combining English teaching with business practice. Even when business knowledge is integrated into English teaching, teaching materials are vacuous, rigid and hardly pertinent. Students are even more limited in business expertise and practice, along with a lack of awareness for field surveys and business knowledge collection. Consequently, it's hard for English learning to work its way in business practice.

\subsection{Teaching of English for business}

Economic globalization comes as a general trend of economic development. As an important means of communication worldwide, English will gain wider application in business activities during economic globalization. Therefore, it's very imperative to consider business practice in English teaching. First of all, teaching objective must be clear. Business English teaching should aim at fostering both English proficiency and business skills of students so as to exert its actual role in cultivating integrated talents. Then English teaching materials should have relevance to business activities, and the teaching contents should reflect the characteristics of business industry. Through this, students can integrate their learning mentality into business situations, improving their English proficiency as well as business skills. Finally, attention should be paid to emotional factors in English teaching. It's suggested to inspire students to learn business knowledge and cultivate their efficiency, competency and collaboration spirit according to their emotional needs. Taking situational teaching for example, students are grouped based on their individuality. Each of them in a group has their own say and chance to bring their specialty into full play. In this case, students have a sense of collective strength, which therefore elevates their ideological qualities about solidarity, collaboration and win-win thought.

\section{APPLICATION AND ANALYSIS OF ENGLISH TEACHING METHODS}

\subsection{Application of English teaching methods}

With the development of quality education, teaching methods have been even more diversified. In English teaching, the common methods are case method, situational method, discussion method and stratification teaching method.

\subsection{Application of case method}

The key of case method lies in the design of cases along with information collection and preparation by students. In this student-centered method, students need to fully utilize their basic knowledge to collect information, study problems and accomplish preview tasks. Case method stresses the cultivation of students' thinking, innovation and reaction capabilities. Firstly, cases are oriented based on teaching contents. Cases can be collected by students or specified by the teacher under whose guidance students will get to know the cases before class. Secondly, relevant topics can be designed according to cases and teaching contents before preview tasks are assigned. Students can search books and internet for related information of their interest in preparation for their participation in the teaching. For example, if "contract" is designed as the case topic, then students should pay attention to negotiations and signing of a contract. Meanwhile, they need to know negotiating convention and manners in English. Only in this way can they have a chance of active participation in teaching process. Thirdly, topic discussions are initiated around case analysis in teaching process. They are conducted first by group and later by class. Finally, the teacher will make a summary of selected cases, evaluating students' opinions and solutions. Students are enlightened for deep engagement in English teaching and richer knowledge of business.

\subsection{Application of situational method}

Situational method, which is an effective English teaching method, brings students into business situations through vivid scenes. In this case, students are more likely to learn how English is applied in business activities. Firstly, the situations are created through multimedia or scene design, such as the situation of airport transfer, accommodation arrangement or a reception and farewell party. When introduced into vivid sensory experience, students can integrate into the business situations to learn English. For example, in a shopping situation, students learn to find out customers' preferences and guide them to purchase goods. For another example, in a situation of company introduction, students learn how to articulate the development and scale of a company in English. Secondly, teachers are supposed to reinforce students' understanding of their role in the situation. Under teachers' guidance, students communicate with each other in the given business situation with the English vocabulary and sentence patterns they have learned. Through this, students can enhance their memory of knowledge. For example, in a reception and farewell party, students are divided into different groups, each of which is assigned with a role. Then each group conducts discussions around their role. Meanwhile, they try to understand the 
application of English vocabulary, sentence patterns and related business knowledge. A member will be selected for role play on behalf of his/her group, such as delivering a welcome speech in English. They will get deeper into the application of English knowledge in this process. Finally, an evaluation is made on the performance of students, who are enlightened to process knowledge to build a culture of business English. In this way, students apply English to communication by combining English learning with business activities.

\subsection{Application of other teaching methods}

In discussion method, the teacher first designs questions or plans based on teaching content before grouping students. For example, if the teaching content is about agent solicitation and requirements, relevant questions or topics will be arranged. Students discuss these questions and topics in English, through which they summarize relevant knowledge and know more about it. Then comments are made on students' performance. Through the combination of topic discussions with English teaching contents, the teacher improves students' understanding and application capability of knowledge. In stratification teaching method, students are stratified based on their individuality, English grounding and learning habits. Different types of teaching methods are conducted for different levels of students, with a view to improving the English competency of all the students. Besides, there are task-based teaching approach, cooperative teaching and interest-simulated teaching method. To ensure English teaching effects, teachers need scientifically adopt and apply the teaching method based on teaching contents and students' characteristics.

\subsection{Analysis on the application of English teaching methods}

Business English values the practicality of English, focusing on understanding, absorption and transformation of knowledge in teaching process. The final goal is to transform English knowledge into communication competency in business activities. In teaching process, a single method can hardly bring about satisfying results. Instead, it will lead English teaching to the path of formalism and dogmatism, which violates the basic concept of personnel training in colleges and universities. Therefore, the following points should be kept in mind in business English teaching. Firstly, teaching materials should receive enough attention. It's necessary for teachers to go deep into teaching materials. They are also encouraged to reasonably expand knowledge around teaching materials. Besides, teaching contents should be designed along with appropriate methods on the basis of teaching materials. Secondly, it's important to achieve comprehensive application of different teaching methods to bring out their own specialty to the best. Through flexible combination of these methods, desirable teaching results can be accomplished. For example, when case method is combined with stratification method, cases of different difficulty will be assigned to students according to their competency. Students acquire a sense of achievement in the process, thus gaining greater interest, passion and confidence in English learning. In this way, English teaching realizes its effectiveness. Thirdly, as the master of teaching methods, teachers' comprehensive competency is closely connected to the effects of teaching methods. So business English teaching has high expectations for teachers. On one hand, teachers need to be rich in business expertise and English teaching experience. They're supposed to properly integrate business knowledge into English teaching. So students can experience real-life business situations and improve their business communication skills. Then English fully accomplishes its role of communication. On the other hand, teachers need to be versatile. They should exhibit good communication skills, ability to apply modern teaching technology and so on, which lays foundations for diversification of teaching methods. Fourthly, whatever the teaching method is, effective cooperation between teachers and students is an important part of English teaching. This decides the effects of English teaching methods. For example, in situational method, students find it difficult to understand the lesson without preview before class or enough guidance of teachers. In this case, no matter how fully teachers are prepared, their teaching enthusiasm will be frustrated. Throughout the class, teachers have to perform their solo in classroom and indoctrinate students with knowledge. Hence, it's crucial to motivate students' initiatives and enthusiasm. For one thing, harmonious and friendly teacher-student relationship contributes to students' active cooperation in teaching. Students will also open their heart to teachers who will then help solve students' problems in preview and review. For another, teachers' observation on students' reaction help them make adjustments to classroom atmosphere and therefore effectively control the whole teaching process. Students are enlightened to explore, process and innovate knowledge under teachers' guidance. In this way, they are able to put what they learn into practice. Fifthly, features of each teaching method should be given full play. Meanwhile, preparation before class and tutorship after class are both important. For example, in situational method, vivid situational experience arouses students' interest in and thirst for knowledge. This helps improve students' knowledge application skills. However, it requires a process for students to accept new knowledge, 
especially for them to integrate business knowledge such as business etiquette and business buzzwords. To get students well versed in the knowledge is the teaching focus. Tutorship after class is an important way to achieve this. On one hand, students can have a better command of the English knowledge they have learned through homework. Meanwhile, they can integrate business etiquette and business buzzwords into English learning. Their understanding and knowledge of business English learning are established in this process. On the other hand, teachers can scientifically tease out what students have learned through specific tutorship after class. Students are more likely to understand and digest the knowledge. They also develop scientific learning methods and increase their learning independence. All these contribute to the progress of English teaching.

\section{CONCLUSIONS}

English is a widely used skill in modern society. The training of high-quality and modern talents should give priority to improvement of English application capabilities. Business English teaching improves
English teaching and students' learning with clearer directions and objectives. Besides, joint and scientific application of different teaching methods makes for the combination of English with business knowledge. Students have a good grasp and application of comprehensive knowledge through their participation in English teaching. Consequently, the overall quality of personnel cultivated in universities and colleges is upgraded. Students are expected to adapt to society better and make greater contributions with their own intellect.

\section{REFERENCES}

[1] Lu Shuang. Preliminary Study on Pedagogy of Business English in English for Special Purpose. Juanzong 2014(03):87-87.

[2] Zhang Yazhi. Study on Application of Case Method in Business English Teaching. Journal of Kaifeng Institute of Education 2014(01):179-180.

[3] Kang Jian. Analysis on Application of Task-based Teaching Method in Business English Intensive Reading. The Guide of Science \& Education 2014(05):144-145. 